MACGregor, A. G., and Others, 1949. The Geology of Central Ayrshire. Mem. Geol. Survey.

MACGregor, M., and MACGregor, A. G., 1948, British Regional Geology : The Midland Valley of Scotland. Mem. Geol. Survey.

RicheY, J. E., and Others, 1930. The Geology of North Ayrshire. Mem. Geol. Survey.

_- 1939. The Dykes of Scotland. Trans. Edin. Geol. Soc., xiii, pp. 393-435. and KENNEDY, W. Q., 1939. The Moine and Sub-Moine Series of Morar, Inverness-shire. Bull. Geol. Survey, Gt. Britain, ii, p. 26.

Wilson, G. V., and Others, 1935. The Geology of the Orkneys. Mem. Geol. Survey.

Wilson, J. S. Grant., 1898. Summary of Progress, Geol. Survey Great Britain, pp. 152-3.

\title{
ANNOUNCEMENT
}

\section{INTERNATIONAL GEOLOGICAL CONGRESS}

The nineteenth International Geological Congress will be held in Algiers from 8-15th September, 1952. "A " excursions are being organized for periods of five to fifteen days before the Congress, and " $\mathrm{C}$ " excursions for eight to eighteen days after the Congress; in addition, a series of " $D$ " excursions to French W. Africa are being arranged for October. The membership fee has been fixed at $3000 \mathrm{Fr}$., and those proposing to attend are asked to communicate with-

M. le Secrétaire Générale,

Comité Algérien d'Organisation du XIX ${ }^{\mathrm{e}}$ Congrès Géologique International,

Faculté des Sciences, Alger, Algeria.

Those who do not propose to attend are nevertheless asked to fill in and return Form A accompanying the First Circular, to assist in the compilation of a world list of geologists ; in this connection, the Secretary-General will be glad to receive names and addresses of any geologists who may not have received the circular. 